\title{
KEBIASAAN SARAPAN DAN PRESTASI BELAJAR SISWA SD DI KOTA BOGOR TAHUN 2013
}

\author{
Ima Karimah ${ }^{1}$ \\ ${ }^{1}$ Prodi DIII Gizi Tasikmalaya, Jurusan Gizi Poltekkes Tasikmalaya, \\ Poltekkes Kemenkes Tasikmalaya \\ ima.karimah@dosenpoltekkestasikmalaya.ac.id
}

\begin{abstract}
ABSTRAK
Salah satu permasalahan gizi anak Indonesia adalah kebiasaan sarapan yang kurang baik. Masih banyak anak Indonesia yang tidak sarapan atau sarapan dengan kualitas gizi rendah. Sarapan memiliki manfaat dalam mendukung status gizi maupun prestasi belajar anak. Tujuan penelitian ini adalah untuk mengkaji kaitan antara kebiasaan sarapan, status gizi, dan prestasi belajar pada anak sekolah dasar. Penelitian ini termasuk jenis penelitian observasional analitik dengan menggunakan desain studi cross sectional.Sampel penelitian ini adalah siswa sekolah dasar kelas 5 di 2 Sekolah Dasar swasta favorit yang ada di Kota Bogor, yaitu SD Bina Insani dan SD Insan Kamil sebanyak 108 siswa. Hasil penelitian menunjukkan bahwa sebagian besar siswa sudah memiliki kebiasaan sarapan yang baik. Sebanyak $62.0 \%$ siswa selalu sarapan setiap paginya. Kebiasaan sarapan ini tidak berhubungan dengan prestasi belajar siswa ( $p$ value $=0.673$ ). Rata-rata nilai siswa yang selalu sarapan lebih rendah dibandingkan dengan siswa yang sarapannya kadangn-kadang. Namun, kebiasaan sarapan berhubungan dengan status gizi siswa $(p=0.047)$. Siswa yang selalu sarapan cenderung lebih banyak yang gemuk daripada yang status gizinya normal.
\end{abstract}

Kata Kunci : kebiasaan sarapan, status gizi, prestasi belajar

\begin{abstract}
One of the problems of Indonesian child nutrition is the bad breakfast habits. There are still many Indonesian children who don't have breakfast or breakfast with low nutritional quality. Breakfast has benefits in supporting nutritional status and children's learning achievement. The purpose of this study was to examine the relationship between breakfast habits, nutritional status, and learning achievement in elementary school children. This research is an observational analytic study usingstudy design cross-sectional. The sample of this study was grade 5 elementary school students in 2 favorite private elementary schools in the city of Bogor, namely SD Bina Insani and SD Insan Kamil as many as 108 students. The results showed that most students already had good breakfast habits. As many as $62.0 \%$ of students always eat breakfast every morning. This breakfast habit is not related to student achievement ( $p$-value $=$ 0.673 ). The average value of students who always eat breakfast is lower than students who eat breakfast sometimes. However, breakfast habits are related to the nutritional status of students $(p$-value $=0.047)$. Students who always eat breakfast tend to be more fat than those with normal nutritional status.
\end{abstract}

Keywords: breakfast habits, nutritional status, learning achievement

\section{PENDAHULUAN}

Salah satu permasalahan gizi anak Indonesia adalah kebiasaan sarapan.
Sarapan merupakan kegiatan makan dan minum yang aman dan bergizi di pagi hari sebelum sekolah atau bekerja, memenuhi 
$15-30 \%$ dari kebutuhan harian dalam rangka mewujudkan hidup sehat, aktif dan cerdas (Hardinsyah 2012). Review dari beberapa penelitian di Indonesia menunjukkan bahwa 17-59\% anak-anak Indonesia tidak melakukan sarapan (PSS 2018). Hasil penelitian Irdiana dan Nindya (2017) menunjukkan bahwa sebagian besar responden (SMAN N 3 Surabaya) belum memiliki kebiasaan sarapan setiap hari.

Hasil penelitian Hardinsyah dan Aries (2012) menunjukkan hampir $44.6 \%$ anak usia sekolah sarapan dengan kualitas gizi rendah, yaitu asupan energi sarapan kurang dari $15 \%$. Demikian dengan hasil penelitian Nita et al. (2016), menunjukkan bahwa sebagian besar sumbangan kalori sarapan anak masih kurang dari $25 \%$.

Sarapan penting bagi setiap orang untuk mengawali aktivitas sepanjang hari. Menurut Gibson dan Gunn (2011), sarapan dapat memenuhi kebutuhan zat gizi di pagi hari dan bermanfaat dalam mencegah hipoglikemia, menstabilkan kadar glukosa darah, mencegah dehidrasi setelah berpuasa sepanjang malam

Sarapan yang cukup membekali tubuh untuk berpikir dan beraktivitas fisik secara optimal. Bagi anak sekolah sarapan terbukti dapat meningkatkan kemampuan belajar dan stamina anak (Gibson dan Gunn 2011). Anak yang sarapan memiliki daya juang belajar dan konsentrasi atau perhatian yang lebih baik (Hardinsyah 2013). Kebiasaan sarapan pada anak SD berhubungan dengan prestasi belajarnya. Sarapan dapat bermanfaat dalam memelihara ketahanan tubuh agar dapat belajar dengan baik sehingga dapat fokus dalam menerima pelajaran (Sukiniarti 2015). Demikian dengan penelitian Khalida et al. (2015), kebiasaan sarapan berhubungan dengan prestasi belajar matematika dan Bahasa Indonesia.

Selain itu, sarapan dapat mencegah kejadian kegemukan. Kebiasaan sarapan dapat menanamkan pola makan yang baik. Hasil penelitian $\mathrm{Kral}$ et al. (2011), menunjukkan bahwa anak-anak yang terbiasa sarapan tidak akan makan berlebih di waktu makan berikutnya. Kebiasaan tidak sarapan beresiko meningkatkan lingkar pinggang, kadartotal kolesterol darah, dan kadar LDL darah (Smith et al. 2010).

Hasil studi yang dilakukan Yunawati et al. (2015), menunjukkan bahwa tidak terdapat hubungan antara kebiasaan sarapan dengan status gizi. Demikian dengan hasil penelitian Irdiana dan Nindya (2017) menunjukkan hasil yang sama. Penelitian Kusprasetia (2016), menunjukkan bahwa frekuensi sarapan tidak memiliki hubungan yang signifikan dengan status gizi. adanya hubungan kebiasaan sarapan pagi dengan status gizi.

Berdasarkan data-data yang diuraikan diatas, maka penulis tertarik untuk mengkaji bagaimana kaitan antara kebiasaan sarapan, status gizi, dan prestasi belajar pada anak sekolah dasar.

\section{METODE PENELITIAN}

Penelitian ini termasuk jenis penelitian observasional analitik dengan menggunakan desain studi cross sectional. Penelitian ini dilaksanakan di Kota Bogor, berlangsung selama 3 bulan dari bulan Agustus sampai dengan Oktober 2013. Populasi dalam penelitian ini adalah siswa sekolah dasar kelas 5 di 2 Sekolah Dasar swasta favorit yang ada di Kota Bogor, yaitu SD Bina Insani dan SD Insan Kamil. Penentuan lokasi penelitian dilakukan secara purposive dengan pertimbangan bahwa kondisi sosial ekonomi menengah ke atas sehingga jumlah siswa yang mengalami kegemukan cukup banyak.

Jumlah minimum sampel ditentukan berdasarkan pendugaan proporsi dengan selang kepercayaan $95 \%$, proporsi populasi (P) sebesar $7.7 \%$ (Hermina dan Jahari 2007) dan presisi 0.05. Berdasarkan hasil perhitungan, jumlah minimum sampel dalam penelitian ini sebanyak 108 siswa. Sampel dipilih secara purposive berdasarkan kesediaan dari pihak sekolah dan anak untuk mengikuti penelitian ini. Kriteria inklusi dalam penelitian ini adalahsubyek terdaftar sebagai siswa sekolah tersebut, tidak memiliki penyakit seperti asma, dan tergolong status gizi kegemukan (termasuk obes dan overweight) dan status gizi normal. Siswa dikategorikan kegemukan apabila IMT/U +1 $\mathrm{SD}<Z \leq+2 \mathrm{SD}$ dan IMT/U $>+2 \mathrm{SD}$, dan normal apabila IMT/U -2 SD $<Z \leq+1$ SD (Kemenkes 2011).

Data yang dikumpulkan dalam penelitian ini terdiri dari data karakteristik anak, status gizi, kebiasaan sarapan, dan prestasi belajar. Data kebiasaan sarapan diperoleh melalui wawancara dengan kuesioner. Prestasi belajar dalam penelitian ini diperoleh dari nilai tes hasil belajar anak. Nilai yang diambil dari mata pelajaran 
Matematika, Bahasa Indonesia, IPA, IPS, dan Bahasa Inggris. Penentuan status gizi anak dilakukan dengan pengukuran antropometri yaitu berat badan dan tinggi badan. Data status gizi siswa diperoleh dengan mengukur secara langsung tinggi badan contoh menggunakan microtoise dengan ketelitian $0.1 \mathrm{~cm}$, dan data berat badan anak diukur secara langsung dengan menggunakan timbangan berat badan digital merk Kriss. Pengkategorian status gizi siswa berdasarkan IMT/U(Kemenkes RI 2011).

\section{HASIL PENELITIAN}

Berikut ini adalah karakteristik subjek penelitian ini:

Tabel 1 Sebaran karakteristik siswa

\begin{tabular}{|c|c|c|c|c|c|c|}
\hline \multirow{2}{*}{$\begin{array}{l}\text { Karakteristik } \\
\text { subjek }\end{array}$} & \multicolumn{2}{|c|}{ Normal } & \multicolumn{2}{|c|}{ Kegemukan } & \multicolumn{2}{|c|}{ Total } \\
\hline & $\mathrm{n}$ & $\%$ & $\mathrm{n}$ & $\%$ & $\mathrm{n}$ & $\%$ \\
\hline \multicolumn{7}{|c|}{ Jenis kelamin } \\
\hline Laki-laki & 11 & 28.2 & 41 & 59.4 & 52 & 48.1 \\
\hline Perempuan & 28 & 71.8 & 28 & 40.6 & 56 & 51.9 \\
\hline Total & 39 & 100 & 69 & 100 & 108 & 100 \\
\hline \multicolumn{7}{|c|}{ Umur (tahun) } \\
\hline 10 & 32 & 82.1 & 46 & 66.7 & 78 & 72.2 \\
\hline 11 & 7 & 17.9 & 23 & 33.3 & 30 & 27.8 \\
\hline Total & 39 & 100 & 69 & 100 & 108 & 100 \\
\hline
\end{tabular}

Hasil penelitian ini sejalan dengan data Riset Kesehatan Dasar tahun 2010, yang menunjukkan bahwa kejadian kegemukan pada anak-anak usia sekolah dasar lebih banyak terjadi pada anak laki-laki (10.7\%) dibandingkan dengan perempuan (7.7\%). Demikian dengan penelitian Adiningrum (2008), proporsi terbesar kegemukan terjadi pada anak sekolah dasar laki-laki di Jakarta Selatan $(7.1 \%)$.

Hasil penelitian ini sejalan dengan penelitian di beberapa negara misalnya prevalensi overweight dan obesitas di Delhi, India lebih banyak terjadi pada lakilaki dibandingkan perempuan (Kaur et al. 2008; Chhatwal et al. 2004). Demikian pula penelitian di Australia, prevalensi obesitas pada anak sekolah dasar lebih tinggi pada laki-laki (6.4\%) dibandingkan perempuan (5.6\%). Prevalensi obesitas pada anak sekolah menengah atas juga sama lebih tinggi pada laki-laki (7.7\%) dibandingkan perempuan (5.7\%) (Odea 2008).

Penelitian di Swis juga menunjukkan hasil yang sama. Prevalensi overweight pada anak laki-laki di Swis adalah 15\% sedangkan anak perempuan $12.4 \%$. Prevalensi obesitas anak laki-laki 1.8\% sedangkan anak perempuan $1.7 \%$ (Lasserre et al. 2007). Studi pada anakanak dan remaja di Cyprus (Savva et al. 2002) juga demikian.

Prevalensi kegemukan (overweight dan obesitas) yang lebih banyak terjadi pada laki-laki kemungkinan berkaitan dengan pertumbuhan dan perkembangan anak. Pada akhir masa anak-anak, perempuan sudah mulai pubertas. Massa pubertas anak perempuan lebih dulu terjadi dibandingkan dengan laki-laki. Oleh karena itu, anak perempuan sudah mulai memikirkan penampilan dan cenderung mengatur pola makannya, sementara anak laki-laki cenderung kurang peduli dengan penampilannya.

Perbedaan cara pandang mengenai penampilan dikaitkan dengan beberapa penelitian yang mengkaji body image pada remaja. Kemungkinan anak perempuan pada usia sekolah dasar sekarang sudah memperhatikan body image nya. Penelitian Lingga (2011), menunjukkan bahwa sebagian besar remaja perempuan merasa cukup penting memperhatikan bentuk tubuhnya.Beberapa penelitian menunjukkan bahwa permasalahan body image lebih banyak pada perempuan dibandingkan dengan laki-laki. Perempuan cenderung mempermasalahkan berat badan atau bentuk badannya dibandingkan dengan laki-laki. Penelitian di Australia menunjukkan bahwa anak yang memiliki keinginan kurus lebih tinggi pada anak perempuan $(39 \%)$ dibandingkan dengan laki-laki (26\%) pada anak usia 8-12 tahun. Demikian dengan penelitian pada anak usia 9-11 tahun suku Kaukasia, anak perempuan $(33 \%)$ lebih khawatir terhadap lemak tubuhnya dibandingkan anak laki-laki (17\%) (Thompson \& Smolak 2001). 
Tabel 2 Kebiasaan sarapan dan prestasi belajar

\begin{tabular}{lcccc}
\multicolumn{5}{c}{ siswa } \\
\hline $\begin{array}{c}\text { Kebiasaan } \\
\text { Sarapan }\end{array}$ & $\mathbf{n}$ & $\%$ & $\begin{array}{c}\text { Rata-rata } \\
\text { nilai } \pm \text { SD }\end{array}$ & p-value \\
\hline Selalu & 67 & 62.0 & $84,4 \pm 7.7$ & 0.673 \\
Kadang-kadang & 41 & 38.0 & $85,0 \pm 6.8$ & 0 \\
\hline
\end{tabular}

Tabel 2 menunjukkan kebiasaan sarapan dan prestasi belajar siswa. Berdasarkan tabel 2 dapat diketahui bahwa sebagian besar responden memiliki kebiasaan sarapan dengan kategori selalu. Selain itu, rata-rata nilai siswa sedikit lebih tinggi pada anak yang sarapannya kadang-kadang. Hasil analisis statistik menunjukkan tidak terdapatnya hubungan antara kebiasaan sarapan dengan rata-rata nilai siswa ( $p$ value $=0.673$ ) .

Tabel 3 Kebiasaan sarapan dan status gizi siswa

\begin{tabular}{|c|c|c|c|c|c|c|c|}
\hline \multirow{2}{*}{$\begin{array}{c}\text { Kebiasaan } \\
\text { Sarapan }\end{array}$} & \multicolumn{2}{|c|}{ Normal } & \multicolumn{2}{|c|}{ Gemuk } & \multicolumn{2}{|c|}{ Total } & \multirow{2}{*}{$\begin{array}{c}\text { p- } \\
\text { value }\end{array}$} \\
\hline & n & $\%$ & n & $\%$ & $\mathbf{N}$ & $\%$ & \\
\hline Selalu & 29 & 43.3 & 38 & 56.7 & 67 & 62.0 & \\
\hline $\begin{array}{l}\text { Kadang- } \\
\text { kadang }\end{array}$ & 10 & 24.4 & 31 & 75.6 & 41 & 38.0 & 0.047 \\
\hline Total & 39 & & 69 & & 108 & 100 & \\
\hline
\end{tabular}

Tabel 3 menunjukkan kebiasaan sarapan dan status gizi siswa. Berdasarkan tabel 3 dapat diketahui bahwa baik yang sarapannya selalu maupun kadang-kadang lebih banyak berstatus gizi gemuk daripada normal. Hasil analisis statistik menunjukkan adanya hubungan antara kebiasaan sarapan dengan status gizi siswa $(p$-value $=$ 0.047).

\section{PEMBAHASAN}

Sebagian besar siswa sudah memiliki kebiasaan sarapan yang baik pada penelitian ini. Sebanyak $62.0 \%$ siswa selalu sarapan setiap paginya. Responden pada penelitian ini adalah siswa yang berada di sekolah golongan menengah $k e$ atas. Kemungkinan orang tua siswa pada penelitian ini sudah faham mengenai pentingnya sarapan pada anak. Hasil penelitian Karimah (2014), menunjukkan bahwa pendidikan orang tua siswa yang menjadi responden pada penelitian ini sebagian besar lulus perguruan tinggi (83.3\% ibu dan $70.4 \%$ ayah). Pendidikan dapat mengambarkan pengetahuan orang tua, termasuk pengetahuan tentang gizi, khususnya pentingnya sarapan. Namun, pada penelitian ini tidak mengkaji pengetahuan gizi orang tua sehingga tidak dapat tergambarkan bagaimana pengetahuan orang tua siswa yang menjadi responden.

Selain itu, saat ini media sudah banyak yang mempromosikan mengenai pentingnya sarapan. Pengaruh media yang intensif memungkinkan adanya perubahan pengetahuan orang tua mengenai pentingnya sarapan. Oleh karena itu, sebelum sekolah para orang tua menyuruh anaknya untuk sarapan terlebih dahulu.

Hasil penelitian ini menunjukkan tidak adanya hubungan antara kebiasaan sarapan dengan prestasi belajar siswa. Rata-rata nilai siswa yang selalu sarapan adalah 84.4 sedangkan siswa yang sarapannya kadang-kadang yaitu 85.0. Berdasarkan hasil wawancara dengan beberapa siswa, banyak diantara siswa yang mengikuti kegiatan les di luar jam sekolah. Baik yang diadakan internal oleh sekolahnya maupun di lembaga bimbingan belajar tertentu. Kegiatan belajar tambahan membuat anak sering membuka materi pelajaran sehingga dapat meningkatkan prestasi belajarnya. Hal ini diduga menjadi faktor lain yang berpengaruh terhadap prestasi belajar anak.

Hasil penelitian ini sejalan dengan penelitian Rahmiwati (2014), yang menunjukkan tidak adanya hubungan antara kebiasaan sarapan dengan prestasi belajar siswa. Hal ini terjadi karena banyak faktor yang mempengaruhi prestasi belajar selain kebiasaan sarapan diantaranya intektual,psikologis, faktor pengaturan di sekolah,faktor sosial di sekolah, dan faktor situasional disekolah yang tidak diteliti dalam penelitian ini.

Selain itu, faktor lain yang memengaruhi prestasi belajar anak diantaranya adalah latar belakang sosial ekonomi orang tua, perhatian orang tua, teman, dan lingkungan belajar anak. Faktor lingkungan ini cukup berperan karena pada rentang usia 8-10 tahun (usia SD) anak sudah mulai berhubungan dengan kelompok sosial tertentu, yang pengaruhnya terhadap anak cukup besar. Lingkungan keluarga yang paling dekat dengan anak juga pengaruhnya cukup besar. Peran orang tua dalam membimbing belajar anak sangat berperan dalam menentukan keberhasilan pencapaian prestasi anak. Keterlibatan orang tua dalam membantu belajar anak dengan tulus, tidak menyalahkan maupun mengkritik akan mendorong minat belajar anak sehingga mendorong pencapaian prestasi belajar anak yang baik. Prestasi 
anak dapat dipengaruhi oleh tingkat kecerdasan yang dimilikinya.

Penelitian Maharani

menunjukkan bahwa tingkat kecerdasan berhubungan nyata dengan prestasi akademik anak SMA. Pada penelitian ini tidak diteliti tingkat kecerdasandari masingmasing anak. Para ahli psikologi mengartikan kecerdasan sebagai keseluruhan kemampuan individu untuk memperoleh pengetahuan, menguasainya, dan mempraktekannya dalam pemecahan suatu masalah. Tingkatkecerdasan merupakan salah satu faktor yang memengaruhi prestasi belajar anak.Menurur Ramadhy dan Permadi (2001), kecerdasan merupakan domain kemampuan intelektual manusia yang berkaitan dengan kemampuan melakukan sesuatu dengan tepat, cepat, dan cermat. Tingkat kecerdasan seseorang dipengaruhi oleh faktor genetik, lingkungan, maupun gizi. Tingkat kecerdasan orang tua berhubungan kuat dengan $I Q$ anak dan status gizi(Webb et al. 2005).

Penelitian ini menunjukkan adanya hubungan antara kebiasaan sarapan dengan status gizi. Siswa yang selalu sarapan cenderung lebih banyak berstatus gizi gemuk daripada normal. Hal ini diduga asupan sarapan pada anak dengan status gizi gemuk jumlahnya banyak, terutama asupan lemak. Hasil penelitian Karimah (2014) menunjukkan bahwa rata-rata konsumsi energi anak yang mengalami kegemukan $(2839 \pm 983$ Kalori) lebih tinggi dibandingkan anak yang status gizinya normal (2604 \pm 1232 Kalori). Rata-rata konsumsi karbohidrat anak kegemukan (390.2 \pm 135.2 gram) lebih tinggi dibandingkan anak yang status gizinya normal (367.6 \pm 177.6 gram). Demikian dengan rata-rata konsumsi lemak anak yang kegemukan $(104.9 \pm 50.3$ gram) lebih tinggi dibandingkan anak yang status gizinya normal (92.3 \pm 52.6 gram). Rata-rata konsumsi protein anak yang kegemukan $(82.8 \pm 36.1 \mathrm{gram})$ lebih tinggi dibandingkan anak yang normal (79.6 \pm 49.4 gram). Tingginya rata-rata konsumsi zat gizi pada anak kegemukan mungkin merupakan salah satu penyebab timbulnya kegemukan pada anak.

Kejadian overweight atau obesitas seringkali dikaitkan dengan kelebihan konsumsi lemak, terutama lemak jenuh. Hasil penelitianKarimah (2014), menunjukkan bahwa presentase kontribusi lemak berlebih (>30\%) pada anak kegemukan lebih tinggi dibandingkan anak yang berstatus gizi normal. Rata-rata kontribusi lemak anak kegemukan $(32.2 \pm 7.8 \%)$ lebih tinggi dibandingkan anak yang berstatus gizi normal $(31.0 \pm 7.0 \%)$. Asupan gizi yang berlebih menyebabkan keseimbangan energi positif sehingga dapat meningkatan berat badan.

\section{KESIMPULAN}

Sebagian besar siswa sudah memiliki kebiasaan sarapan yang baik. Sebanyak $62.0 \%$ siswa selalu sarapan setiap paginya. Kebiasaan sarapan ini tidak berhubungan dengan prestasi belajar siswa ( $p$ value $=$ 0.673 ). Rata-rata nilai siswa yang selalu sarapan lebih rendah dibandingkan dengan siswa yang sarapannya kadang-kadang. Namun, kebiasaan sarapan berhubungan dengan status gizi siswa $(p=0.047)$. Siswa yang selalu sarapan cenderung lebih banyak yang gemuk daripada yang status gizinya normal.

\section{SARAN}

Perlu adanya penelitian lebih lanjut untuk melihat keterkaitan antara kebiasaan sarapan, status gizi, dan prestasi belajar siswa dengan jumlah sampel yang lebih besar. Selain itu, penelitian selanjutnya perlu mempertimbangkan faktor-faktor lain yang mempengaruhi keberhasilan prestasi belajar siswa.

Adapun keterbatasan dalam penelitian ini adalah tidak melihat kuantitas dari asupan sarapan anak sehingga tidak dapat terukur seberapa besar sumbangsih asupan sarapan anak-anak terhadap angka kecukupan gizi anak.

\section{DAFTAR PUSTAKA}

Chhatwal J, Verma M, Riar SK, (2004). Obesity among pre-adolescent and adolescents of a developing country (India). Asia Pac J Clin Nutr. 13(3):2315.

Gibson SA, Gunn P, 2011. What's for breakfast?Nutritional Implication of Breakfast Habits:Insight From NDNS Dietary Record. Nutrition Bulletin. 35 (78-86).

Hardinsyah, Aries M, (2012). Jenis Pangan Sarapan dan Peranannya Dalam Asupan Gizi Harian Anak Usia 6-12 Tahun di Indonesia. Jurnal Gizi dan Pangan. Vol. 7. No. 2. 
Hardinsyah, (2012). Masalah dan Pentingnya Sarapan bagi Anak. Materi Simposium Sarapan Sehat tanggal 16 Juni 2012. Jakarta.

Hardinsyah, (2013). Sarapan Sehat Salah Satu Pilar Gizi Seimbang. Materi Simposium Sarapan Sehat tanggal 8 Januari 2013. Jakarta.

Hermina, Jahari AB, (2007). Ukuran lingkar pergelangan tangan sebagai indikator kegemukan pada anak usia sekolah dasar di Kota Bogor Jawa Barat. Jurnal Gizi Indonesia. Puslitbang Gizi dan Makanan Depkes RI Bogor, 30(2):137142.

Irdiana W, Nindya TS, (2017). Hubungan Kebiasaan Sarapan dan Asupan Zat Gizi dengan Status Gizi Siswi SMAN 3 Surabaya. Atika dan Sumarmi. Open acces under CC BY-SA license. DOI:10.20473/amnt.v1.i3.2017.227-235.

Karimah I, (2014). Aktivitas Fisik, Kebugaran, Dan Prestasi Belajar Pada Anak Sekolah Dasar Normal Dan Kegemukan Di Bogor. Sekolah Pascasarjana. [tesis]. Bogor (ID): Institut Pertanian Bogor.

Kaur S, Sachdev HPS, Dwivedi SN, Lakshmy R, Kapil U, (2008). Prevalence of overweight and obesity amongs school children in Delhi, India. Asia Pac J Clin Nutr. 17 (4):592-596.

[Kemenkes] Kementerian Kesehatan RI, (2011). Keputusan meteri kesehatan RI Nomor:1995/MENKES/SK/XII/2010 tentang Standar Antropometri Penilaian Status Gizi Anak. Jakarta (ID): Direktorat Jenderal Bina Gizi dan Kesehatan Ibu dan Anak.

Khalida E, Fadlyana E, Somasetia DH, (2015). Hubungan Kebiasaan Sarapan dan Prestasi Belajar dan Fungsi Kognitif Pada Anak Sekolah Dasar. Sari Pediatri. Vol. 17. No. 2.

Kral TVE, Whiteford LM, Heo M, Faith MS, (2011). Effect of Eating Breakfast Compared With Skipping Breakfast on Ratings of Appetite and Intake at Subsequent Meals in 8 to 10 Years olsd Children. American Journal of Clinical Nutrition. 93 (284-291).

Kusprasetia MT, (2016). Hubungan Antara Kebiasaan Sarapan dengan Status Gizi dan Prestasi Belajat pada Anak Sekolah Dasar di Kota Bogor. Departemen IImu Gizi. [skripsi]. Bogor (ID): Institut Pertanian Bogor.
Lassere AM, Chiolero A, Catcat F, Paccaud $F$, Bovet $P$, (2007). Overweight in Swis children and associations with children's and parent's characteristic. Obesity. 15:2912-2919.

Lingga M, (2011). Studi tentang pengetahuan gizi, kebiasaan makan, aktivitas fisik, status gizi dan body imange remaja putri yang berstatus gizi normal dan gemuk/obes di SMA Budi Mulia Bogor. Bogor [skripsi]. Bogor (ID): Institut Pertanian Bogor.

Nita MHD, Hanim D, Prasodjo, Poncorini E, Suminah, (2016). Hubungan Sarapan dan Sosial Budaya dengan Status Gizi Anak SD Pulau Semau Kabupaten Kupang (Relationship Breakfast and Socio-Cultural With Nutritional Status of Children Elementary School in Semau Island Kupang Regency. Penelitian Gizi Makanan. Vol. 39. No. 2 (119-127).

Pergizi Pangan Indonesia, (2018). Pendidikan Sarapan Sehat Menuju Generasi Sehat Berprestasi dalam Rangka Hari Kesehatan Dunia dan Hari Pendidikan Nasional April-Mei 2018.

Rahmiwati A, (2014). Hubungan Sarapan Pagi Dengan Prestasi Belajar Siswa Sekolah Dasar. Jurnal IImu Kesehatan Masyarakat. Vol. 5. No. 3.

Ramadhy S, Permadi D, (2001). Bagaimana Mengembangkan Kecerdasan (Metoda Baru untuk Mengoptimalkan Fungsi Otak Manusia). Bandung (ID): PT Sarana Panca Karya Nusa.

Savva SC, Kourides Y, Tornaritis M. SavvaEpiphaniou M, Chadjigeorgiou C, Kafatos A, (2002). Obesity in children and adolescents in Cyprus, prevalence and predisposing factors. Internationan Journal of Obesity. 26:1036-1045. DOI:10.1038/sj.ijo.0802042.

Smith KJ, Gall SL, McNaughton SA, Blizzard L, Dwyer T, Venn AJ, (2010). Skipping Breakfast: Longitudinal Association With Cardiometabolic Risk Factors In The Chilhood Determinants of Adult Healthy Study. American Journal of Clinical Nutrition. Vol 92 (1316-1325).

Sukiniarti, (2015). Kebiasaan Makan Pagi Pada Anak Usia SD dan Hubungannya Dengan Kesehatan dan Prestasi Belajar.Jurnal Pendidikan Biologi Indonesia. Vol 1 No. 3 (315-321).

Thompson JK, Smolak L, (2001). Body Image, Eating Disorders, and Obesity in Youth, Assesment, Prevention, and 
Treatment. United States of America (US): American Psychological Association.

Webb KE, Horton NJ, Katz DL, (2005). Parental IQ and cognitive development of malnourished Indonesian children. European Journal of Clinical Nutrition. 59:618-620.

DOI:10.1038/sj.ejcn.1602103.

Yunawati I, Hadi H, Julia M, (2015). Kebiasaaan Sarapan Tidak
Berhubungan dengan Status Gizi Anak Sekolah Dasar di Kabupaten Timor Tengah Selatan, Provinsi Nusa Tenggara Timur. Jurnal Gizi dan Dietetik Indonesia. Vol. 3. No. 2 (77-86). 